Check for updates

Cite this: RSC Adv., 2017, 7, 29129

\title{
Gum odina: an emerging gut modulating approach in colorectal cancer prevention
}

\author{
Debmalya Mitra, (D) a Abhishek Basu, (D) ${ }^{\mathrm{b}}$ Bhaskar Das, (D) a Aditya Kr. Jena, (D) ${ }^{a}$ \\ Arnab De, (D) a Mousumi Das, (D) a Sudin Bhattacharya (D) ${ }^{\text {b }}$ and Amalesh Samanta (D) *a
}

It is well established that prebiotics have a profound influence on colonic microbiota which in turn play an essential role in ameliorating the host's health. This study is focused on Gum Odina (GO), a reported prebiotic in our earlier work, and its impact on colorectal cancer (CRC). GO, upon utilization by probiotics, liberates short-chain fatty acids, acetic acid $\left(0.864 \pm 0.050 \mathrm{mg} \mathrm{m}^{-1}\right)$ and butyric acid $(2.303$ $\pm 0.083 \mathrm{mg} \mathrm{ml}^{-1}$ ) predominantly and increases colonization of Lactobacillus sp. and Bifidobacterium sp. in a gut simulator. The in vivo preventive study of CRC was conducted on Swiss albino mice using 1,2dimethyl hydrazine (DMH) along with inulin and $\mathrm{GO}$ as the standard and test prebiotic, respectively. Scanning electron micrographs of the colon depict that the severity of mucosal dysplasia, flat lesions and loss of goblet cells was quite low in the GO group compared to the DMH alone treated group. The same was noticed in the histomicrograph in terms of alteration of the colonic architecture and abnormalities in the submucosa. Administration of DMH also caused oxidative burst as the levels of reactive oxygen species and lipid peroxidation significantly increased $(p<0.05)$ but reduced by $29.35 \%$ and $27.65 \%$, respectively, in the GO group. Moreover, the levels of glutathione, glutathione-S-transferase, superoxide dismutase and catalase in the colonic tissues significantly increased $(p<0.05)$ by $31.26 \%, 10.96 \%, 12.4 \%$ and $6.37 \%$, respectively, when compared to IN, a standard prebiotic. Thus, GO possesses CRCpreventing along with antioxidant properties and slows the overall tumor genesis process.

Received 10th April 2017 Accepted 18th May 2017 DOI: $10.1039 / c 7 r a 04077 f$ rsc.li/rsc-advances

\section{Introduction}

The use of prebiotics for an effective gut ecology is a current trend of research, ${ }^{1}$ as the demand in natural products claiming health benefits is increasing day to day. This developing aspect of glycoscience is coming into the limelight due to increased health consciousness and consumer awareness ${ }^{2}$ leading to the development of new bioactive compounds working on the principle of "prevention is better than a cure". ${ }^{3}$

Prebiotics are carbohydrates ${ }^{4}$ that resist digestion and absorption in the upper parts of the gastrointestinal tract ${ }^{5}$ of the host, selectively utilizing specific bacterial strains, ${ }^{6}$ and confer health benefits. ${ }^{7}$ Considering the profound health benefits of prebiotics, their development from new natural sources like Gum Odina (GO), ${ }^{1}$ mushroom polysaccharide, ${ }^{8}$ Aloe vera mucilage, ${ }^{9}$ artichoke fibers (Cynara cardunculus L. var. scolymus) ${ }^{10}$ almond skin, ${ }^{\mathbf{1 1}}$ bamboo shoots ${ }^{\mathbf{1 2}}$ (Phyllostachys praecox) and Stevia rebaudiana (Bertoni) roots $^{\mathbf{1 3}}$ is being carried out. Prebiotics not only prevent gastrointestinal diseases ${ }^{\mathbf{1 4}}$ by limiting the space of survival for pathogenic bacteria ${ }^{15}$ but also improve

${ }^{a}$ Division of Microbiology, Department of Pharmaceutical Technology, Jadavpur University, Kolkata, India, 700032. E-mail: asamanta61@yahoo.co.in; Tel: +91 33 24572617; +919432315461

${ }^{b}$ Department of Cancer Chemoprevention, Chittaranjan National Cancer Institute, Kolkata, India human health by positive stimulation of the immune system, ${ }^{\mathbf{1 6}}$ reduction of intestinal inflammatory diseases and cholesterol levels, ${ }^{14}$ regulation of blood glucose, ${ }^{17}$ and treatment of pochutis $^{\mathbf{1 8}}$ and osteoporosis. ${ }^{2}$

Due to recent occupational hazards and dietary habits like high red meat intake, colorectal cancer (CRC) has become the most deadly cancer in the world at present. ${ }^{18}$ CRC is mainly caused by mutation in tumor suppression genes ${ }^{19}$ and prebiotics act as a chemopreventive agent by removing food-borne mutagens. ${ }^{20}$ Pathogenic bacteria, upon colonization in the intestine, contribute to progression of CRC by inducing gut inflammation, ${ }^{21}$ up-regulating inflammatory genes (NF-kB, IL-6, IL-8 and IL-18), ${ }^{22}$ epithelial damage and promoting prooncogenic responses. ${ }^{23}$ Prebiotics, conversely, manipulate gut microbiota $^{24}$ i.e. selectively stimulate Lactobacilli sp. and Bifidobacterium sp. immunomodulation ${ }^{25}$ by increasing sIgA in the gut environment, ${ }^{\mathbf{1}}$ enhance apoptosis, ${ }^{26}$ and down-regulate the expression levels of COX-2, NF-kB and iNOS. ${ }^{27}$ Moreover, upon utilization, prebiotics also liberate $\mathrm{SCFA}^{28}$ which slows the overall tumerigenesis ${ }^{29}$ by providing energy to colonocytes.

GO has been used previously in formulations like tablet binders, ${ }^{30}$ emulsifying agents ${ }^{31}$ and matrices for sustained drug release, ${ }^{32}$ and in designing chitosan-GO complex coacervates for colon targeted drug delivery. ${ }^{33}$ The chemical composition ${ }^{34}$ and branched structure ${ }^{35}$ of this polysaccharide is reported 
earlier which mainly comprises D-galactose (63.70\%). Chemically, GO resembles inulin (IN), ${ }^{36}$ which is an established prebiotic in our previous work. ${ }^{1}$ Thus, this work aims to understand the colonization pattern of bacteria in the gut, the quantification of SCFA liberated and the related anticancer properties, when this natural polysaccharide is incorporated in the diet.

\section{Methodology}

\subsection{Materials}

All of the chemicals and materials used in this experiment were of analytical grade. Brain heart infusion agar, cysteine, de Man, Rogosa and Sharpe agar, Enterococcus agar, Manitol salt agar, Mc. Conkey agar, mucin, pectin, Raffinose-Bifidobacterium agar, starch, xylan, and yeast extract were purchased from HiMedia Laboratories Pvt. Ltd. (Mumbai, India). 1,2-dimethyl hydrazine (DMH), 2',7'-dichlorofluorescin diacetate (DCFH-DA), 5,5'-dithio-bis(2-nitrobenzoic acid), acetic acid (AA), agarose, acetonitrile, arabinogalactan butyric acid (BA), ethidium bromide, EDTA, hydrogen peroxide, HEPES, lactic acid (LA), phosphoric acid, phosphate buffered saline (PBS), propionic acid (PA), pyridine, thiobarbituric acid (TBA), Triton X-100, and tris HCL were procured from Sigma-Aldrich (Steinheim, Germany). Butanol, calcium chloride $\left(\mathrm{CaCl}_{2}\right)$, dextrose, magnesium chloride $\left(\mathrm{MgCl}_{2}\right)$, potassium chloride $(\mathrm{KCl})$, sodium hydroxide $(\mathrm{NaOH})$, sodium dihydrogen phosphate $\left(\mathrm{NaH}_{2} \mathrm{PO}_{4}\right)$, and sodium dodecyl sulphate (SDS), were purchased from Merck Schuchardt OGH (Hohenbrunn, Germany) and formaldehyde, HPLC water, paraffin and sodium chloride $(\mathrm{NaCl})$ were purchased from Merck Specialities Pvt. Ltd (Mumbai, India). Graduated tubes and Microtiter plates used in different assays were purchased from Tarsons Products Pvt. Ltd (New Delhi, India).

\subsection{Live subject statement}

Swiss albino mice used for the experiment were procured from the Indian Institute of Chemical Biology, Kolkata, India. The studies were carried out in strict accordance with the guidelines of the Committee for the Purpose of Control and Supervision of Experiments on Animals (CPCSEA), Ministry of Environment, Forest and Climate Changes, Govt. of India, which is established under Chapter 4, Section 15(1) of the Prevention of Cruelty to Animals Act 1960. The experiments were organized and conducted upon appropriate permission from the Institutional Animal Ethics Committee, Department of Pharmaceutical Technology, Jadavpur University, India, vide no. CPCSEA reg no. $\{(0367 / 01 / \mathrm{C} / \mathrm{CPCSEA})$ India $\}$.

\subsection{Collection and purification of gum}

GO is solid, amber colored exudates liberated from the branch of the plant Odina wodier found in the tropical deciduous forests of West Bengal, India. Upon collection, the gum is dried in a hot air oven at $40{ }^{\circ} \mathrm{C}$ to remove extraneous materials, pulverized and purified as described earlier. The purified gum is

blended in a mechanical blender and kept in air tight containers for further use. ${ }^{37}$

\subsection{Simulator of human intestinal microbial ecosystem (SHIME) run}

SHIME is a multi-compartment dynamic gut model mimicking the entire gastrointestinal tract and physiological conditions of humans. ${ }^{38}$ The experimental run was carried out as described by Wiele et al. with some modifications. The bacteria used for inoculation was from a fecal sample of a healthy adult male volunteer with no recent history of antibiotic treatment. The startup period was 2 weeks for better adaptation of the microbes in the simulator, and was followed by control and two test periods with intervening gaps of adaptation periods between two successive test periods. Normal nutritional medium was fed into the SHIME during the adaptation and control periods, which is detailed in Table 1, but during the treatment period the amount of starch was entirely substituted with test prebiotics. The liquid samples were collected from the $3^{\text {rd }}, 4^{\text {th }}$ and $5^{\text {th }}$ reactors of the SHIME, representing the ascending, transverse and descending colon, respectively, and were stored at $-20{ }^{\circ} \mathrm{C}$ for further analysis. ${ }^{39}$

\subsection{Analysis of LA and SCFAs}

After the SHIME run, the samples collected from the $3^{\text {rd }}, 4^{\text {th }}$ and $5^{\text {th }}$ reactors were divided into aliquots and subjected to detection and quantification of LA and SCFAs (AA, PA \& BA) by ultra high performance liquid chromatography using a UHPLC+ focused system (THERMO SCIENTIFIC, U.S.A) with a C18 column $(250 \mathrm{~mm} \times 4.6 \mathrm{~mm}$ i.d., $5 \mu \mathrm{m})$, Hypersil GOLD (Thermo Scientific, U.S.A) as described previously. ${ }^{1}$ The chromatograms of the study were processed using Chromeleon 7, version 7.2.0.3765 software (Thermo Scientific, U.S.A). All of the analysis was performed in triplicate and the data are presented as mean \pm standard error of the mean.

\subsection{Microbial analysis}

Aliquots of the liquid samples withdrawn were serially diluted up to $10^{-6}$ fold with sterile water and $0.1 \mathrm{ml}$ of sample were plated on agar plates with specific media i.e. de Man, Rogosa and Sharpe agar, Raffinose-Bifidobacterium agar, Enterococcus agar, Mannitol salt agar, MacConkey agar, Brain Heart Infusion Agar, Brain Heart Infusion Agar $+0.5 \mathrm{~g} \mathrm{l}^{-1}$ cysteine for

Table 1 Composition of the growth medium fed into the SHIME

\begin{tabular}{ll} 
Composition & Am \\
\hline Arabinogalactan & 1 \\
Pectin & 2 \\
Xylan & 1 \\
Starch & 4.2 \\
Glucose & 0.4 \\
Yeast extract & 3 \\
Peptone & 1 \\
Mucin & 4 \\
Cysteine & 0.5
\end{tabular}
4.2 0.4 4 0.5 
Lactobacillus sp., Bifidobacterium sp., Enterococci sp., Staphylococci sp., total coliform, total aerobes and total anaerobes, respectively. The plates were incubated at $37^{\circ} \mathrm{C}$ for $24 \mathrm{~h}$ under aerobic and anaerobic conditions as per protocol. ${ }^{39}$ After sufficient incubation the CFU formed were counted.

\subsection{Anticancer studies}

Experiments were carried out with 32 Swiss albino mice which were 6 weeks old and housed in the animal house, Department of Pharmaceutical Technology, with 12-12 h light/dark cycles abiding appropriate rules of the institutional animal ethical committee. The temperature and relative humidity were maintained at $25{ }^{\circ} \mathrm{C} \pm 2$ and $50 \%$ respectively. The animals were fed with a normal diet and water ad libitum up to two weeks for better acclimatization. The composition of the diet is detailed in Table 2. The mice were divided into four groups of eight mice each, and each group also received a probiotic mixture orally ${ }^{40}$ (Lactobacillus plantarum MTCC 6160, Lactobacillus rhamnosus MTCC 8712, Lactobacillus helveticus NCIM 2733, or Lactobacillus acidophilus NCIM 2285) containing $10^{9} \mathrm{CFU}$ in $0.85 \%$ saline per day. GO and IN $(10 \mathrm{mg} / 0.1 \mathrm{ml})^{41}$ were administered using an orogastric gavage.

Positive Control (PC): normal diet + DMH (as per protocol). Negative Control (NC): normal diet.

GO: normal diet + gum odina as prebiotics + DMH (as per protocol).

IN: normal diet + inulin as prebiotics + DMH (as per protocol).

The animals in groups PC, GO and IN were administered with $20 \mathrm{mg} \mathrm{kg}^{-1}$ body weight of DMH in $1 \mathrm{mM}$ of EDTA (pH was adjusted to 6.5 with $1 \mathrm{mM} \mathrm{NaOH}$ ) once a week for eight weeks. At the end of the protocol, the animals were fasted overnight, anesthetized with diethyl ether and sacrificed by cervical dislocation. The colons were excised from the experimental mice, washed thoroughly with PBS, blotted dry and segregated to carry out histopathology, scanning electron microscopy, comet assay and a few biochemical assays. ${ }^{42}$

\subsection{Histopathology}

The freshly removed colon tissues were washed with PBS to remove traces of fecal materials, cut longitudinally and fixed in

Table 2 Composition of the diet fed to the mice

\begin{tabular}{lc}
\hline Compositions & Amount $(\mathrm{g} / 100 \mathrm{gm})$ \\
\hline Starch & 38.5 \\
Sucrose & 25.0 \\
Casein & 20.0 \\
Refined oil & 10.0 \\
Mineral mixture $^{a}$ & 1.0 \\
Vitamin mixture $^{a}$ & 5.0 \\
Choline chloride & 0.2 \\
Methionine & 0.3
\end{tabular}

${ }^{a}$ Vitamin and mineral mixtures were prepared and mixed according to the Association of Official Analytical Chemists, (AOAC Washington, D.C.).
$10 \%$ buffered formaldehyde solution for $48 \mathrm{~h}$. After sufficient fixation, the tissues were subjected to dehydration in ascending grades of alcohol and embedded in paraffin blocks. Thin sections of $5 \mu \mathrm{m}$ were cut out using an ultra-microtome and mounted on glass slides. The tissues were stained (haematoxylin and eosin) and observed under a light binocular microscope. ${ }^{43}$

\subsection{Scanning electron microscope (SEM)}

Colon tissues were washed thrice with PBS and cut longitudinally so that the lumen gets exposed. These tissues were then fragmented into small square pieces and fixed with Carnoy's reagent for $24 \mathrm{~h}$. Test tissues were dehydrated by dipping in ascending grades of alcohol and mounted on carbon tapes. The dried tissues were coated with gold and observed under SEM ${ }^{44}$ (Zeiss SIGMA FE-SEMs, CARL ZEISS, Germany).

\subsection{Detection of DNA damage by alkaline single cell gel electrophoresis (comet assay)}

Comet assay or single cell gel electrophoresis was performed as described by Singh et $a l .{ }^{45}$ with slight modifications. About $2 \times$ $10^{4}$ colon cells were suspended in $75 \mu \mathrm{l}$ of $1.0 \%(\mathrm{w} / \mathrm{v})$ agarose (low melting point grade) and layered onto half-frosted slides which were pre-coated with a thin layer of $1.0 \%(\mathrm{w} / \mathrm{v})$ agarose (normal melting point grade). A third layer of $0.5 \%(\mathrm{w} / \mathrm{v})$ agarose (low melting point grade) was applied on top of it. The cells were lysed by immersing the slides in lysis buffer $(\mathrm{pH} 10.0$, containing $2.5 \mathrm{M} \mathrm{NaCl}, 100 \mathrm{mM}$ EDTA, $10 \mathrm{mM}$ Tris, $10 \%$ DMSO and $1 \%$ Triton $\mathrm{X}-100$ ) for $2 \mathrm{~h}$ at $4{ }^{\circ} \mathrm{C}$; thereafter, the slides were subjected to electrophoresis in a horizontal electrophoresis chamber for $30 \mathrm{~min}$. The electrophoresis buffer was of $\mathrm{pH} 13.1$ and contained $1 \mathrm{mM}$ EDTA and $0.3 \mathrm{M} \mathrm{NaOH}$. Upon electrophoresis, the slides were then neutralized with $0.4 \mathrm{M}$ Tris- $\mathrm{HCl}$, $\mathrm{pH}$ 7.5. The slides were carefully dried at room temperature and stained with ethidium bromide $\left(20 \mu \mathrm{g} \mathrm{ml}^{-1}\right)$ in water. The slides were observed under a fluorescence microscope (DM4000 B, Leica, Germany) with an imaging system installed with Komet 5.5 (Andor Technology, USA). From each slide, cells ( $\geq 100)$ were selected randomly (2 slides/animals in each group) and analysed. The parameters like damaged cell (\%) in each group, average tail length [migration of the DNA from the nucleus $(\mu \mathrm{m})]$ and Olive tail moment [product of tail length and the fraction of total DNA in the tail (arbitrary units)] were taken into consideration.

\subsection{Estimation of cellular reactive oxygen species (ROS) production}

Measurement of ROS in colon tissue was performed using DCFH-DA which is a non-fluorescent probe and gets hydrolyzed by mitochondrial esterase to form DCFH. DCFH, upon oxidation by $\mathrm{H}_{2} \mathrm{O}_{2}$, forms the fluorescent compound $2^{\prime}, 7^{\prime}$-dichlorofluorescein (DCF) which can be detected using $530 \mathrm{~nm}$ band pass filters. Colon tissues were homogenized in Locke's buffer (pH 7.4, containing $140 \mathrm{mM} \mathrm{NaCl}, 5 \mathrm{mM} \mathrm{KCl}, 10 \mathrm{mM}$ HEPES, $1 \mathrm{mM} \mathrm{CaCl}_{2}, 1 \mathrm{mM} \mathrm{MgCl}_{2}$ and $10 \mathrm{mM}$ dextrose) to yield a $10 \%$ w/v homogenate. $250 \mu \mathrm{l}$ of tissue homogenate was taken and 
DCFH-DA $(10 \mu \mathrm{M})$ was added to it, making the final volume of the reaction mixture $3 \mathrm{ml}$. The reaction mixtures were incubated for $45 \mathrm{~min}$ in the dark to allow the formation of DCF. After sufficient incubation, the samples were analyzed (excitation at $485 \mathrm{~nm}$ and emission collected at $530 \mathrm{~nm}$ ) using a spectrofluorometer (Varian Cary Eclipse, CA, USA). All values were expressed as fluorescence intensity per $\mathrm{mg}$ of protein. ${ }^{\mathbf{4 6}}$

\subsection{Estimation of the level of lipid peroxidation (LPO)}

Microsomal fractions were isolated by centrifugation of the tissue homogenate at $35000 \mathrm{~g}$. A reaction mixture containing a microsomal fraction, SDS (8.1\%), AA (20\%) and TBA (0.8\%) was prepared. The reaction mixture was heated at $95{ }^{\circ} \mathrm{C}$ in a water bath for $1 \mathrm{~h}$ which resulted in formation of a pink colored complex (TBA-malondialdehyde complex). The TBAmalondialdehyde complex was extracted using butanol and pyridine $(15: 1)$. The absorbance was measured at $532 \mathrm{~nm}$ with respect to a colorless blank. The level of lipid peroxides formed was expressed as $\mathrm{nM}$ of thiobarbituric acid reactive substances (TBARS) formed per mg of protein using an extinction coefficient of $1.56 \times 10^{5} \mathrm{M}^{-1} \mathrm{~cm}^{-1}$ at $532 \mathrm{~nm}^{47}$

\subsection{Estimation of the glutathione (GSH) levels in the colonocytes}

The GSH levels were estimated in cytosol of colonic cells. The cytosol fraction was isolated by centrifuging colon homogenates at $25000 \mathrm{rpm}$ and collecting the supernatant. $0.1 \mathrm{ml}$ of supernatant was mixed with $2.4 \mathrm{ml}$ of $0.02 \mathrm{M}$ EDTA and kept on ice for $10 \mathrm{~min}$ followed by addition of $2 \mathrm{ml}$ distilled water and $0.5 \mathrm{ml}$ of $50 \%$ TCA. The reaction mixture was further subjected to ice for 10-15 $\mathrm{min}$ and then centrifuged at $3000 \mathrm{~g}$ for $15 \mathrm{~min} .1 \mathrm{ml}$ of supernatant was collected and $2.0 \mathrm{ml}$ of Tris buffer was added to it. Then, $0.05 \mathrm{ml}$ of 5,5-dithio-bis-(2nitrobenzoic acid) (DTNB) was added and mixed thoroughly. Reduction of DTNB by -SH groups was measured spectrophotometrically and the absorbance was recorded at $412 \mathrm{~nm}$ against a reagent blank. The level of GSH was expressed as $\mathrm{nM} \mathrm{mg}{ }^{-1}$ of protein. ${ }^{48}$

\subsection{Estimation of the glutathione- $S$-transferase (GST) levels in the colonocytes}

The activity of GST in the colon cytosol was determined spectrophotometrically from the increase in absorbance at $340 \mathrm{~nm}$ with 1-chloro-2,4-dinitrobenzene (CDNB, $30 \mathrm{mM}$ ) as the substrate and the specific activity of the enzyme was expressed as the formation of CDNB-GSH conjugate per min per $\mathrm{mg}$ of protein. ${ }^{49}$ The cytosolic fragments were collected as described in the GSH estimation and $100 \mu \mathrm{l}$ of it was added to a tube containing $1 \mathrm{ml}$ of $0.3 \mathrm{M}$ phosphate buffer and $100 \mu \mathrm{l}$ of CDNB. A blank was also prepared in the same way with distilled water. $1.7 \mathrm{ml}$ of distilled water was added to each tube and incubated at $30{ }^{\circ} \mathrm{C}$ for $5 \mathrm{~min} .100 \mu \mathrm{l}$ of GSH solution was added to the tubes and the change in the absorbances were recorded. Three readings were taken with intervals of $30 \mathrm{~s}$.

\subsection{Estimation of the superoxide dismutase (SOD) levels in} the colonocytes

The SOD activities in the colon cytosols were determined by quantification of pyrogallol auto-oxidation inhibition and expressed as units per $\mathrm{mg}$ of protein. The reaction mixture for auto-oxidation consisted of $2 \mathrm{ml} 50 \mathrm{mM}$ Tris-HCl buffer $(\mathrm{pH}$ 7.5), $0.4 \mathrm{ml} 2 \mathrm{mM}$ pyrogallol solution and $1.6 \mathrm{ml}$ distilled water. Auto-oxidation of pyrogallol in Tris-HCl buffer was measured by the increase in absorbance at $420 \mathrm{~nm}$. The readings were recorded for $3 \mathrm{~min}$ with each interval being $30 \mathrm{~s}$. One unit of enzyme activity is defined as the amount of enzyme necessary to inhibit the reaction by $50 \% .^{50}$

\subsection{Estimation of the catalase (CAT) levels in the colonocytes}

The activity of CAT in the colon cytosol was determined spectrophotometrically at $240 \mathrm{~nm}$ and expressed as units per $\mathrm{mg}$ of protein, where the unit is the amount of enzyme that liberates half of the peroxide oxygen from $\mathrm{H}_{2} \mathrm{O}_{2}$ in one second at $25^{\circ} \mathrm{C}^{51}$ Briefly, homogenized tissues were centrifuged $\left(4^{\circ} \mathrm{C}\right)$ at $2000 \mathrm{~g}$ for $10 \mathrm{~min}$ and the supernatant was collected as a sample. $10 \mu \mathrm{l}$ of the sample was taken in a tube containing $3.0 \mathrm{ml}$ of $\mathrm{H}_{2} \mathrm{O}_{2}$ phosphate buffer. The time required for a 0.05 OD change was measured at $240 \mathrm{~nm}$ against a blank containing the enzyme source in $\mathrm{H}_{2} \mathrm{O}_{2}$ free phosphate buffer.

\subsection{Statistical analysis}

A graph pad prism (Graph pad prism Inc., version 7.0, Ca, USA) was used to carry out all of the statistical analysis in this study and the results obtained were expressed as mean \pm SD when $n=3$ for studies related to the SHIME and $n=6$ mice per group for the animal studies. Univariate analysis of variance (ANOVA) followed by Tukey's multiple comparison test was performed to determine the significance of GO for CRC prevention. The results at $p<0.05$ were considered statistically significant. ${ }^{43}$

\section{Results and discussion}

\subsection{Analysis of LA and SCFAs}

The presence of $\beta$ linkages ${ }^{\mathbf{1}}$ in GO allows it to pass through the digestive tract which becomes available in the gut ${ }^{52}$ where it is selectively utilized by probiotic bacteria, which in turn generates SCFAs. ${ }^{53}$ The colon vessels were monitored throughout the SHIME run and the samples collected from reactors 3,4 and 5 during the control, IN and GO periods were subjected to detection and quantification of liberated LA and SCFAs. Ultra high performance liquid chromatography using the gradient elution mode, at a flow rate of $1.250 \mathrm{ml} \mathrm{min}^{-1}$ with a run time of $15 \mathrm{~min}$, was performed for the analysis. The retention time (RT) of LA, AA, PA and BA standards were $4.052 \mathrm{~min}, 4.262 \mathrm{~min}$, $9.895 \mathrm{~min}$ and 13.287 min respectively. Fig. 1 depicts LA and SCFAs liberated in various reactors during the control, IN and GO periods of the SHIME run. The amount of LA and SCFAs liberated during the control and test periods are quantified and detailed in Table 3. From Table 3 it is clear that BA was significantly $(p<0.05)$ predominant compared to the other tested 


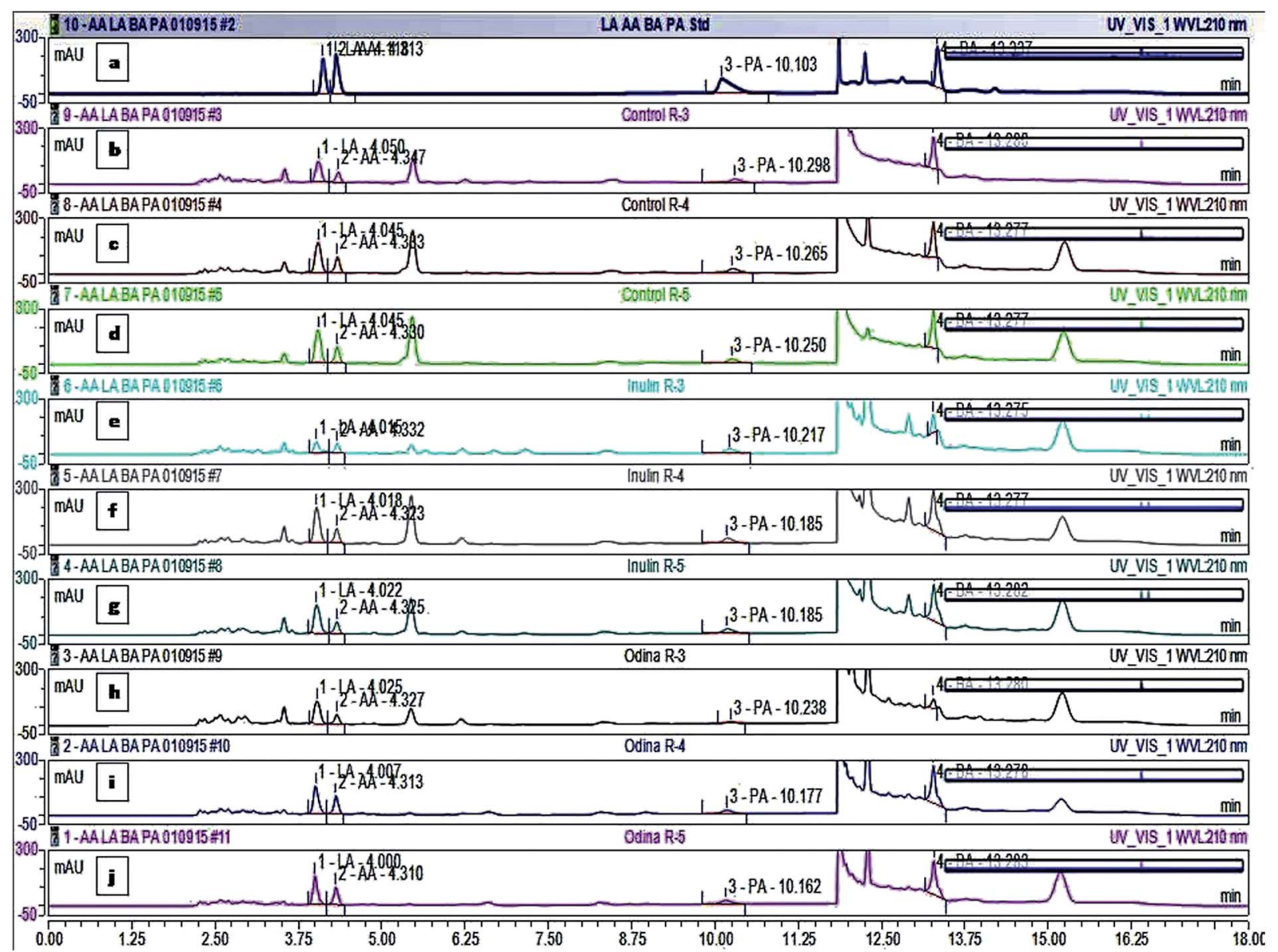

Fig. 1 HPLC chromatograms of: a standard solution containing LA, AA, PA and BA (a), reactor 3 of the control period (b), reactor 4 of the control period (c), reactor 5 of the control period (d), reactor 3 of the test period [IN] (e), reactor 4 of the test period [IN] (f), reactor 5 of the test period [IN] (g), reactor 3 of the test period [GO] (h), reactor 4 of the test period [GO] (i) and reactor 5 of the test period [GO] (j).

acids, with the highest amount being in reactor 4 for IN $(2.646 \pm$ $\left.0.080 \mathrm{mg} \mathrm{ml}^{-1}\right)$. The amount of BA liberated in reactor 4 during the GO period was significantly $(p<0.05)$ equivalent with that of IN which is $30.16 \%$ more than for the control. The LA liberated in reactor 3 during the control period was $1.52 \pm 0.01 \mathrm{mg} \mathrm{ml}^{-1}$ which gradually increased to $2.416 \pm 0.07 \mathrm{mg} \mathrm{ml}^{-1}$ in reactor 5 . Surprisingly, when prebiotics were introduced into the nutritional media the amount of LA and AA significantly $(p<0.05)$ increased from reactor 3 to 4 but a minute fall in the amount was observed in reactor 5 i.e. $13.96 \%$ and $3.80 \%$ for IN and GO respectively, with respect to reactor 4 . A notable increase in PA liberation was seen in reactor $5(36.34 \%)$ with respect to reactor 4 upon supplementation of GO whereas the PA liberation pattern was almost the same as for LA and AA in the control and IN groups. SCFAs, mainly BA, play multiple roles like intestinal barrier function, mineral absorption, cell growth and differentiation, and providing energy to the colonocytes. SCFAs are metabolized differently by cancerous cells than by normal ones. SCFAs interact with GPR41, GPR43 and GPR109A expressed in the gut epithelium and maintain homeostasis by downregulating cell multiplication pathways. ${ }^{54}$ Moreover, these metabolites also upregulate pro-apoptosis by inhibiting histone deacytylases, protein BAK and p21..$^{52,55}$ Thus, SCFAs are one of the major metabolites of prebiotic anaerobic fermentation which in turn lowers the $\mathrm{pH}$ of the colon thus increasing growth of beneficial bacteria and contributing towards the betterment of health. Ammonia levels are tremendously increased upon high intake of a high protein diet, leading to colonocyte proliferation thus increasing the risk of CRC development. ${ }^{56}$ SCFAs, especially BA, interfere with the cell cycle at the G2/M interphase and contribute towards the inhibition of CRC development..$^{52}$

\subsection{Microbial analysis}

It is very difficult to monitor the exact changes in the population shift of selected species in the SHIME and the bacterial population also depends on genetics, age, health status, nutrition, and diet of the benefactor. ${ }^{57}$ Fig. 2 represents the detailed bacterial counts observed in reactors 3,4 , and 5 during the control and test periods (IN and GO) of the SHIME run. The prebiotic substrate selectively stimulates growth of intestinal bacteria, especially Lactobacillus sp. and Bifidobacterium sp. and confers to health and wellbeing. ${ }^{58}$ The plate counts of Lactobacillus sp. and Bifidobacterium sp. in reactor 3 were found to be 
$1.76 \pm 0.12 \log \mathrm{CFU} \mathrm{ml} \mathrm{ml}^{-1}$ and $2.48 \pm 0.28 \mathrm{log} \mathrm{CFU} \mathrm{ml} \mathrm{m}^{-1}$, respectively, during the startup (control) period of the experiment, which increased significantly $(p<0.05)$ to $3.54 \pm 0.11 \mathrm{log}$ CFU ml ${ }^{-1}$ and $3.61 \pm 0.19 \log$ CFU ml ${ }^{-1}$, respectively, during the IN period. Furthermore, the plate counts of Lactobacillus sp. and Bifidobacterium sp. increased significantly to $3.4 \pm 0.17 \mathrm{log}$ $\mathrm{CFU} \mathrm{ml} \mathrm{m}^{-1}$ and $3.28 \pm 0.32 \log \mathrm{CFU} \mathrm{ml} \mathrm{m}^{-1}$, respectively, in the GO period. In reactor 3, the counts of Enterococcus sp., Staphylococcus sp., total anaerobes, total aerobes and total coliform groups were found to be $2.28 \pm 0.41 \log \mathrm{CFU} \mathrm{ml} \mathrm{m}^{-1}, 1.87 \pm$ $0.18 \log \mathrm{CFU} \mathrm{ml} \mathrm{m}^{-1}, 3.39 \pm 0.39 \log \mathrm{CFU} \mathrm{ml} \mathrm{m}^{-1}, 3.64 \pm 0.49 \mathrm{log}$ CFU ml $\mathrm{m}^{-1}$ and $3.50 \pm 0.40 \log \mathrm{CFU} \mathrm{ml} \mathrm{m}^{-1}$, respectively, which remained almost the same during the IN and GO periods, although a significant $(p<0.05)$ fall in the CFU of Enterococcus sp. by $50 \%$ compared with that of the control was observed during the GO period. In reactor 4 the count of Lactobacillus sp. in the control period was observed as $2.81 \pm 0.17 \log \mathrm{CFU} \mathrm{ml}^{-1}$ which increased significantly $(p<0.05)$ to $26.43 \%$ and $16.86 \%$ in the IN and GO periods, respectively. The count of Bifidobacterium $\mathrm{sp}$. was found to be $2.96 \pm 0.27 \mathrm{log} \mathrm{CFU} \mathrm{ml} \mathrm{m}^{-1}$ in the control period which also increased significantly to $21.06 \%$ and $22.30 \%$ in the IN and GO periods, respectively. A slight increase in the count of Staphylococcus sp. $\left(2.85 \pm 0.10 \mathrm{log} \mathrm{CFU} \mathrm{ml^{-1 }}\right)$ was observed in reactor 4 during the control period, which is due to better utilization of sucrose as a carbon source, but significantly $(p<0.05)$ reduced in the IN $(56.14 \%)$ and GO $(66.66 \%)$ periods. Enterococcus sp. also got significantly $(p<0.05)$ eradicated in IN (89.95\%) and GO (88.20\%), from being $2.29 \pm 0.45 \log$ CFU $\mathrm{ml}^{-1}$ during the control period. No drastic change in the total anaerobes, total aerobes and total coliform groups was noted. Bifidobacterium sp. significantly $(p<0.05)$ increased in reactor 5 by $32.55 \%$ and $29.04 \%$ upon supplementation of GO and IN, respectively, compared to during the control period (3.65 \pm $0.31 \log \mathrm{CFU} \mathrm{ml} \mathrm{ml}^{-1}$ ). Although the count of Lactobacillus sp. increased in the test periods (IN and GO), no significant difference was obtained compared to the control period in reactor 5. A steep fall in the count of Enterococcus sp. was also observed in reactor 5 with respect to the control $(2.77 \pm$ $\left.0.6431 \log \mathrm{CFU} \mathrm{ml}^{-1}\right)$ which is significantly $(p<0.05)$ lower in IN $(88.02 \%)$ and GO $(0.92 \%)$, respectively. The CFU counts of the remaining groups varied accordingly with previous reactors and no notable changes were observed in these groups. A large number of bacteria reside in the colon and are known to play a key role in host health. ${ }^{1}$ These bacteria are responsible for the production of various enzymes like $\beta$-glucuronidase, $\beta$-glucosidase, $\beta$-galactosidaase, azoreductase, nitroreductase and 7- $\beta$ dehydrogenase, which are mainly responsible for the conversion of genotoxic compounds. ${ }^{59}$ The concentration of these enzymes is directly related to the gut microbes. GO selectively enhances growth of Lactobacillus sp. and Bifidobacterium sp., over pathogens ${ }^{60}$ like Enterococcus sp., Staphylococcus sp. and coliforms, which in turn reduces the $\beta$-galactosidaase ${ }^{1}$ activity in the gut and suppresses acute inflammation. Absorption of food is greatly influenced by the presence of probiotic bacteria and reduces the ill effect of $\mathrm{DMH}$ generated free radicals. ${ }^{41}$ Lactobacillus acidophilus and Lactobacillus plantarum are highly adhesive to the intestinal mucosa thus obstructing adhesion of 

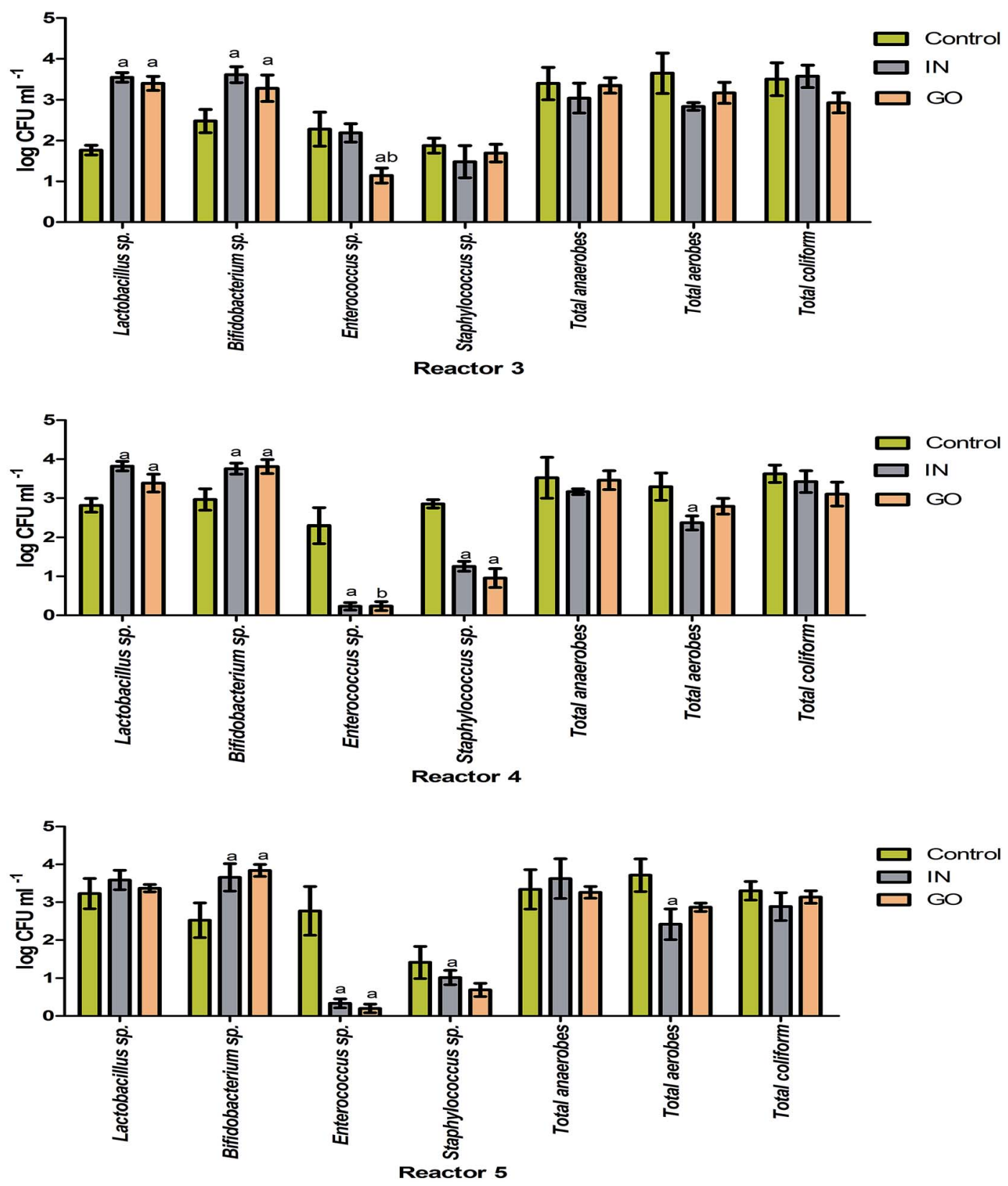

Fig. 2 Plate count of Lactobacillus sp., Bifidobacterium sp., Enterococci sp., Staphylococci sp., total coliforms, total aerobes and total anaerobes in reactors 3, 4, and 5 representing the ascending, transverse and descending colon respectively in the SHIME during the control and test IN and GO periods. Values are expressed as mean \pm SD $(n=3)$. (a) Significantly $(p<0.05)$ different to that of control. (b) Significantly $(p<0.05)$ different to that of IN.

enteropathogens. ${ }^{61}$ Incorporation of GO also results in competitive exclusion of pathogenic microflora by probiotics in terms of nutrients availability.

\subsection{Histopathology}

Improper dietary habits are one of the major causes leading to $\mathrm{CRC}^{62}$ and $\mathrm{DMH}$ used in this study is highly specific and a powerful carcinogen for rodent species. ${ }^{63}$ Histomicrographs of different groups depicting the cellular morphology of the colon are detailed in Fig. 3. The animals in the NC groups had welldefined mucosa with straight tubular crypts of Lieberkühn and intact goblet cells as seen in Fig. 3(A) whereas in Fig. 3(B), i.e. $\mathrm{PC}$, swelling of goblet cells with severe mucosal dysplasia extended until submucosa was observed. The loss of the granular pattern of intestinal crypts along with eosinophilic amorphous necrotic material was also visible. In IN \& GO, the invasiveness of adenoma extended from the mucosa until the muscularis externa but the grade of the dysplastic crypts and number of goblet cells was less in IN than in PC. Moreover, the alteration of the colonic architecture and abnormalities were quite less in the submucosa. On the other hand, swelling of the tubular crypts with heavy lymphocytic infiltration was observed 

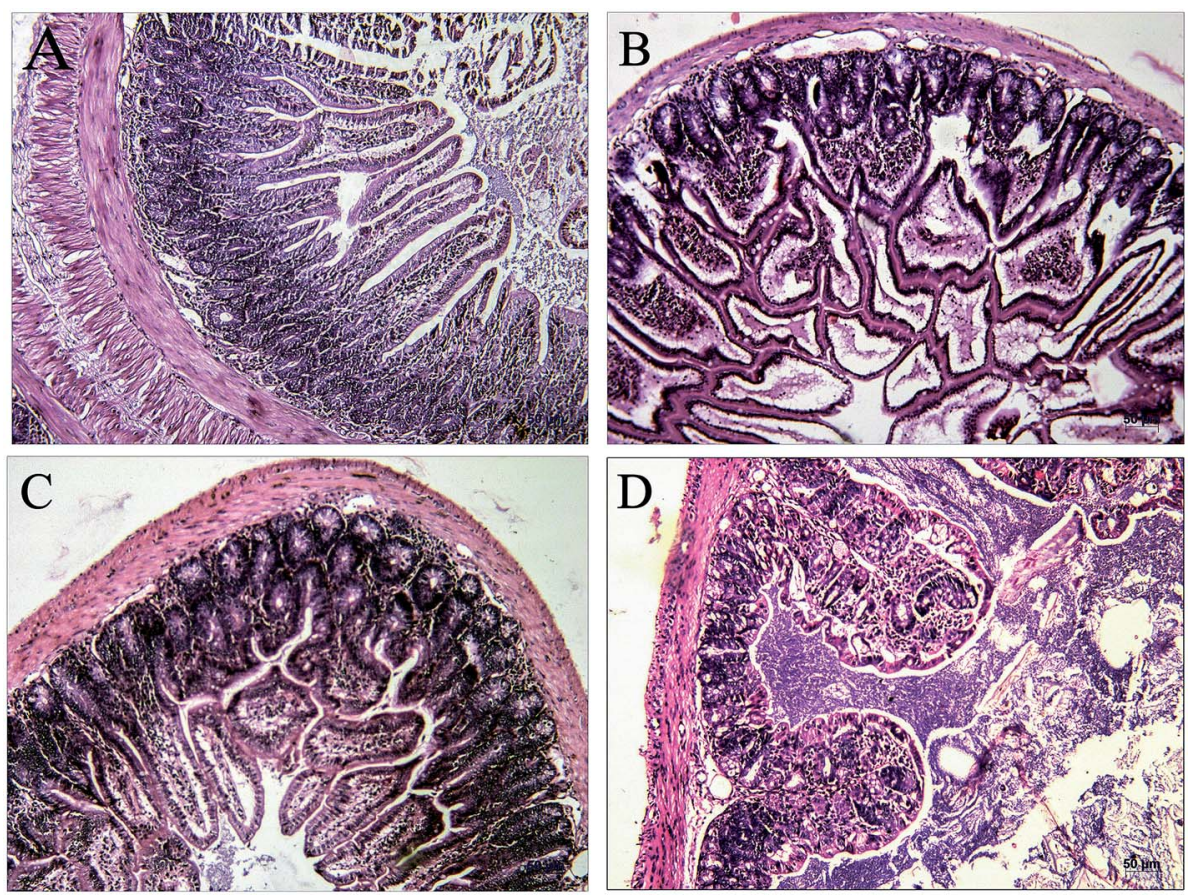

Fig. 3 Cross section of colon (mice), stained with haematoxylin and eosin, depicting the histopathological changes at $100 \times$ and $200 \times$ respectively for each group; scale bar $=50 \mu \mathrm{m}$. NC (a), PC (b), IN (c) and GO (d).

in GO. Surprisingly, the tubular crypts did not completely lose the granular pattern and the muscularis externa was unaltered. The changes observed are associated with an increase in colonization of probiotic bacteria in the gut, i.e. synbiotics. Thus synbiotics prevent chemically induced lesions, aberrant crypt foci (AFC) and occurrence of malignant tumors in the gut mostly by scavenging carcinogenic intermediates and reducing their exposure in the gut. ${ }^{65}$ Data reveals that the administration of prebiotics like GO maintains the architecture of colonic tissues and increases nuclear polarity. ${ }^{64}$ Microorganisms' cell wall elements, especially peptidoglycan and prebiotic polysaccharides, bind to mutagens ${ }^{61}$ which in turn protects goblet cells and increases the secretion of mucin. This secretion of mucin reduces the risk of CRC by preventing injury of colonic tissues. $^{64}$

\subsection{Scanning electron microscopy}

Mutation even in one stem cell at the bottom of a crypt causes uncontrolled growth leading to aberrant crypts and eventually adenoma. ${ }^{66}$ Scanning electron microscopy was performed to study the changes in the surface morphology of the colon associated with administration of 1,2-dimethyl hydrazine which is represented in Fig. 4. Fig. 4(A) is a SEM micrograph of a normal healthy mice colon with intact goblet cells and intestinal crypts ${ }^{67}$ i.e. the NC group, whereas in Fig. 4(B), which is the $\mathrm{PC}$ group, we can see severe mucosal dysplasia with enlarged and swollen crypts termed as flat ACF and massive loss of goblet cells compared to background epithelium. Although large tumors with disorganized and loosely connected epithelial cells are visible in GO as represented in Fig. 4(D), the severity of flat lesions and loss of goblet cells is quite low with respect to PC. The classic elevated ACF, flat lesions formed and epithelial abnormalities associated with tumors in the IN group (Fig. 4(C)) was almost equivalent to that in GO but the no. of large tumors formed was slightly less in the IN group. Thus, synbiotics have the ability to modulate immune parameters in the gutassociated lymphoid tissues reducing the incidence of necrotizing enterocolitis. ${ }^{68}$ Probiotic supplementation also induces apoptosis by expressing (TNF)- $\alpha$, IL 10 and IFN $\gamma \cdot{ }^{69}$ Over expression of GST-P (member of GST superfamily) also accelerates CRC $^{69}$ and SCFAs, BA especially is an energy substrate for colonic epithelium which blocks growth and differentiation of abnormal crypts thus slows the overall cancer progression. ${ }^{52}$

\subsection{Detection of DNA damage by alkaline single cell gel electrophoresis (comet assay)}

Comet assay is a versatile and sensitive method to detect DNA damage. Fig. 5 depicts comets of colonocytes formed in different mice groups. From the results summarized in Table 4, it is clear that the DNA damage \% in the DMH alone treated group was $38.4 \pm 2.2 \%$ which is $89.06 \%$ significantly $(p<0.05$ ) higher than that of the NC group. The damage was $44.79 \%$ and $61.45 \%$ significantly $(p<0.05)$ less compared to the DMH alone group when gum IN and GO was supplemented as standard and test prebiotics, respectively. The tail length of the normal control was found to be $3.5 \pm 0.58 \mu \mathrm{m}$ which eventually increased by $90.30 \%$ in colonocytes of the DMH alone group indicating severe breakage and DNA migration towards the anode, whereas in IN and GO it significantly $(p<0.05)$ reduced 

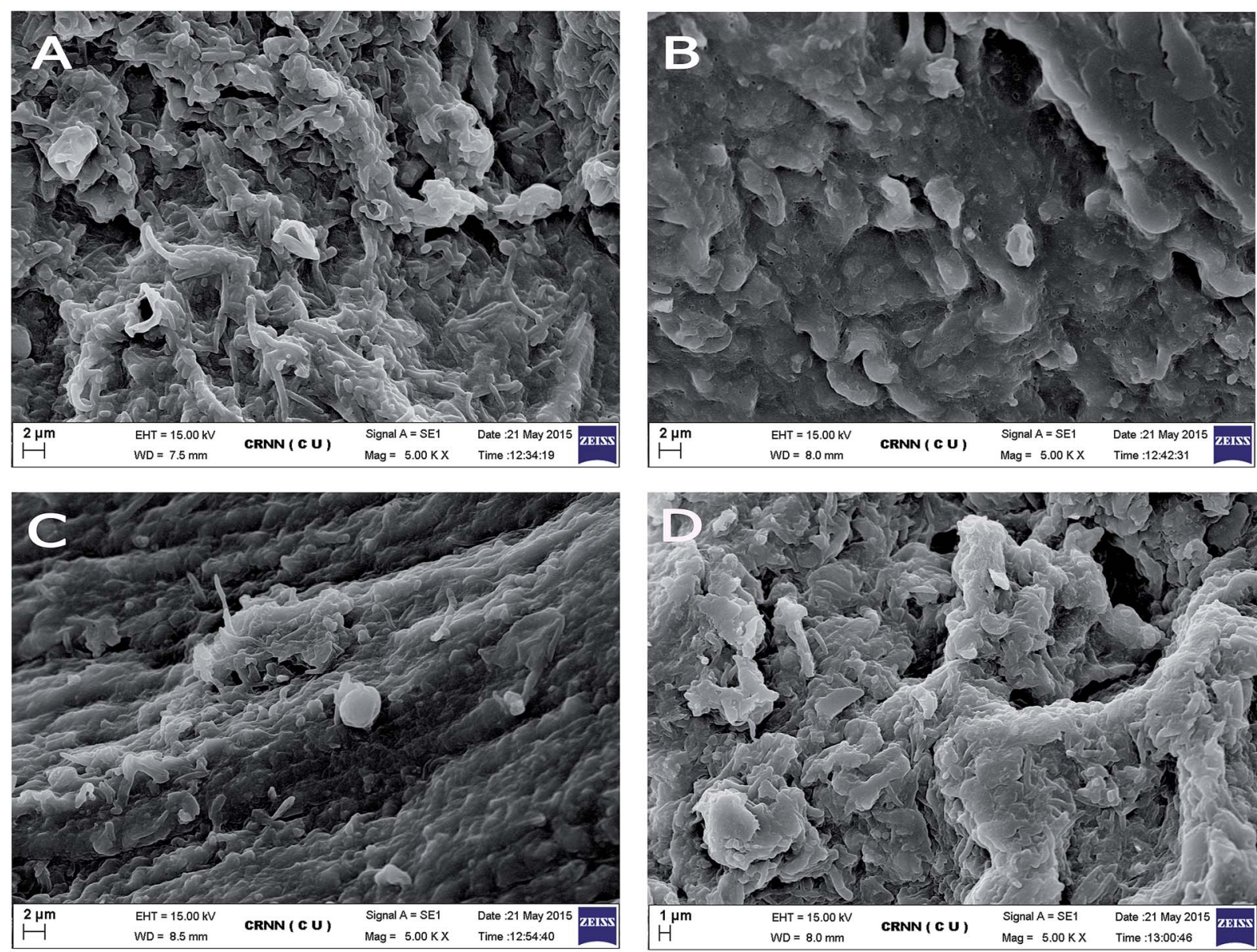

Fig. 4 Scanning electron micrographs of colons (mice) showing morphological changes: (a) NC, (b) PC, (c) IN and (d) GO

by $48.47 \%$ and $71.74 \%$, respectively. $\mathrm{DMH}$ also induced extended olive tail movement; treatment with prebiotics before and during the test periods reduced the olive tail movement significantly $(p<0.05)$ by $63.09 \%$ and $77.38 \%$ for IN and GO, respectively. Intake of dietary xenobiotics causes production of heterocyclic aromatic amines, polycyclic aromatic hydrocarbons and nitrites. These compounds are responsible for mutations in the colonic epithelial cells by creating imbalance of intestinal microbiota, disruption of intestinal barrier function, decrease in mucin production and induction of secondary bile acids. The DNA damage in colonocytes ultimately leads to secondary tumors. Probiotics reduce the formation of secondary bile acids by physically binding to primary bile acids and other carcinogens ${ }^{61}$ and prebiotics ${ }^{70}$ on the other hand maintain gut microbiota and SCFAs liberated reduce the DNA damage by lowering the luminal $\mathrm{pH}$, altering DNA-methylation and enhancing apoptosis to eliminate DNA damaged cells thus contributing towards CRC management. ${ }^{71}$ A recent study also demonstrated that consumption of probiotic yogurt for 6 weeks resulted in reduced feacal water genotoxicity agent in HT29clone 19A. ${ }^{72}$ Probiotics also contribute towards folate production which plays a major role in DNA methylation and aids against DNA damage. Resistant starch also inactivates the
P450-mediated monooxygenase system accounting for tumor suppression. ${ }^{61}$

\subsection{Estimation of cellular ROS production}

Higher levels of dietary xenobiotics, ${ }^{73}$ which are mainly due to improper food habits, generate oxidative stress which is a leading cause of CRC. ${ }^{74} \mathrm{DMH}$ is a potential carcinogen ${ }^{63}$ and its administration caused oxidative burst as the levels of ROS in the positive control got significantly higher $(p<0.05)$ by $53.16 \%$ than those of the normal or negative control. This burst is due to an imbalance between free radical generation and antioxidant levels. ${ }^{75}$ Surprisingly, a significant $(p<0.05)$ downfall in ROS levels by $29.35 \%$ and $14.99 \%$ was observed when GO and IN were incorporated into the diet i.e. test and standard prebiotics, respectively. The observed changes in ROS levels are detailed and represented in Fig. 6(A). Lactic acid bacteria can reduce the activity of various procarcinogenic enzymes capable of generating oxidative stress by improving absorption of food and scavenging free radicals generated. ${ }^{63}$ Colonic fermentation of GO selectively enhances growth of probiotics and produces 16 carbon SCFAs. BA among all SCFAs exhibits the highest antimutagenic effect by inducting GST, up-regulating alkaline phosphatase. It also mediates the histone hyperacetylationmediated pathway and regulates cyclin D1, thus initiating 

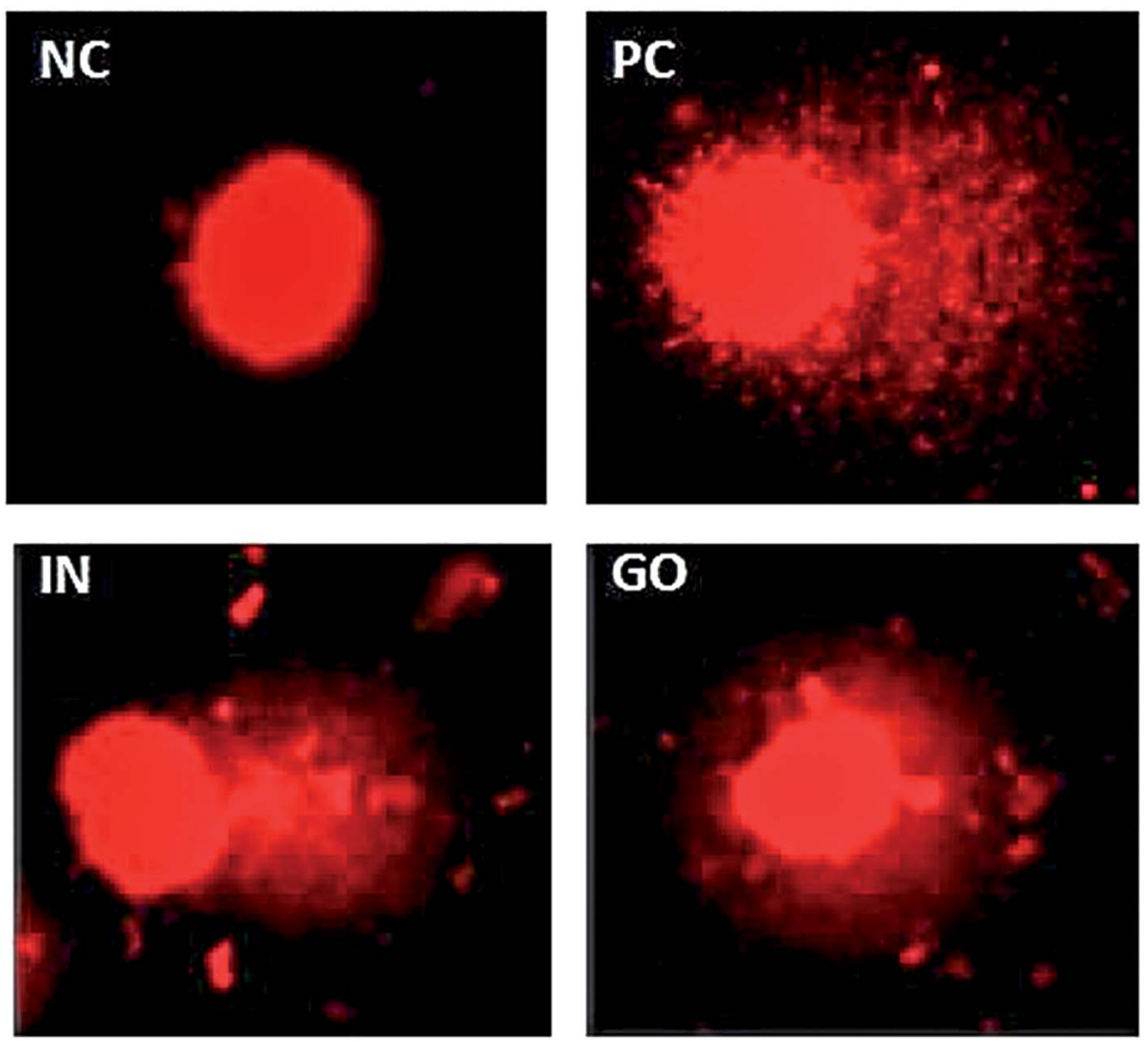

Fig. 5 Photographs showing comet of colonocytes of different mice groups: (a) NC, (b) PC, (c) IN and (d) GO.

Table 4 Representation of damaged cells (\%), tail length and olive movement of different mice groups

\begin{tabular}{lccc}
\hline Groups & Damaged cells $(\%)$ & Tail length $(\mu \mathrm{m})$ & Olive tail moment \\
\hline NC & $4.2 \pm 0.85$ & $3.5 \pm 0.58$ & $0.41 \pm 0.06$ \\
PC & $38.4 \pm 2.2^{a}$ & $36.1 \pm 1.8^{a}$ & $8.4 \pm 0.45^{a}$ \\
IN & $21.2 \pm 1.8^{a, b}$ & $18.6 \pm 1.2^{a, b}$ & $3.1 \pm 0.55^{a, b}$ \\
GO & $14.8 \pm 0.95^{a, b, c}$ & $10.2 \pm 0.85^{a, b, c}$ & $1.9 \pm 0.35^{a, b, c}$
\end{tabular}

${ }^{a}$ Significantly $(p<0.05)$ different to that of NC. ${ }^{b}$ Significantly $(p<0.05)$ different to that of PC. ${ }^{c}$ Significantly $(p<0.05)$ different to that of IN.

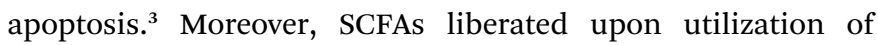
prebiotics trigger various enzymatic ${ }^{76}$ and non-enzymatic antioxidants which play a vital role in maintaining homeostasis.

\subsection{Estimation of the level of lipid LPO}

LPO is another route by which reactive species exert their deleterious effect, increasing lipid hydroperoxides in the cell and disrupting its components. ${ }^{77}$ LPO also degrades to mutagenic aldehyde products which are carcinogenic. ${ }^{78}$ Fig. 6(B) represents the changes in the LPO levels of different groups studied in this experiment. The LPO levels in colonic tissues of the normal or NC group were significantly $(p<0.05)$ lower by $42.45 \%$ than those of the DMH only administered group or PC. In the case of mice from GO, the elevation in LPO levels tends towards normal and significantly $(p<0.05)$ reduced by $27.65 \%$ when compared with the positive control. The reduction of LPO levels was significantly $(p<0.05)$ more in GO than in the IN group which only reduced by $11.99 \%$ compared with that of PC. Administration of probiotic bacteria leads to a $42.13 \%$ decrease in mean tumor and improves absorption of food in intestine. ${ }^{\mathbf{4 1}}$ The mutual action of lactic acid bacteria and prebiotics, i.e. synbiotics, scavenges the produced free radicals by binding and degrading potential carcinogenic and mutagenic compounds thus attenuating lipid peroxidation. ${ }^{79}$

\subsection{Estimation of the GSH levels in the colonocytes}

GSH acts as a second line of defence against generated free radicals. ${ }^{80}$ Fig. $6(\mathrm{C})$ shows the status of non-enzymatic antioxidant (GSH) in the control and test groups of mice. It is clear from Fig. 6(C) that the GSH levels in the normal healthy mice colon were $46.85 \pm 4.70 \mathrm{nM}$ which drastically reduced by $66.50 \%$ in the DMH administered group or PC. The GSH levels significantly $(p<0.05)$ increased to $23.24 \pm 3.20 \mathrm{nM}$ and $33.81 \pm$ $4.80 \mathrm{nM}$ in the mice groups administered with IN and GO, respectively. Thus, the GSH levels were quite elevated in GO $(53.40 \%)$ compared to that of the cancer group which is also 31 . $26 \%$ higher when compared with IN, a standard prebiotic. It is reported that feeding of a combination diet (i.e. synbiotics) ameliorates GSH liberation which in turn inhibits alteration of membrane fluidity, cellular redox imbalance and shutting off 

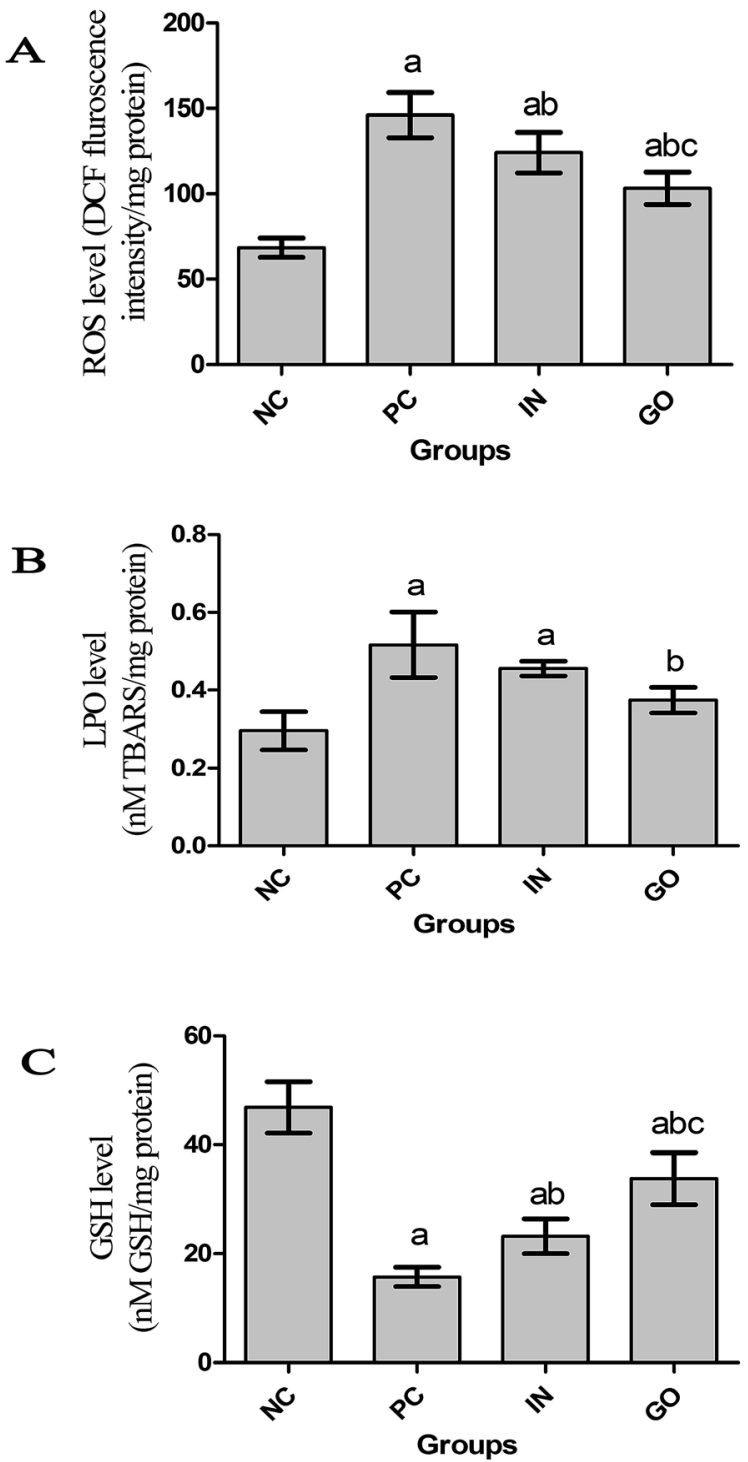

Fig. 6 Effect of GO with respect to IN (a standard prebiotic) on oxidant and anti-oxidant status in experimental colon carcinogenesis. (a) ROS level, (b) LPO level and (c) GSH level values are expressed as mean \pm SD $(n=6)$. (a) Significantly $(p<0.05)$ different to that of NC, (b) significantly $(p<0.05)$ different to that of PC and (c) significantly $(p<$ 0.05 ) different to that of IN.

immune functions, thus reducing damages caused by LPO. ${ }^{\mathbf{8 0}}$ Moreover, GSH also confers a selective growth advantage in neoplastic cells. ${ }^{\mathbf{8 1}}$

\subsection{Estimation of the GST levels in the colonocytes}

GST protects cells from oxidative stress by catalyzing conjugation of GSH with different electrophilic compounds via sulfhydryl groups, thus rendering them inactive. ${ }^{82}$ The activity of GST significantly $(p<0.05)$ decreased in the colonic tissues of the $\mathrm{DMH}$ alone administered mice by $39.15 \%$, as represented in Fig. 7(A), compared to that of the control mice group which was found to be $304.05 \pm 30.0 \mathrm{nM}$. The activity was found to be significantly $(p<0.05)$ higher by $16.05 \%$ than PC in the test
A

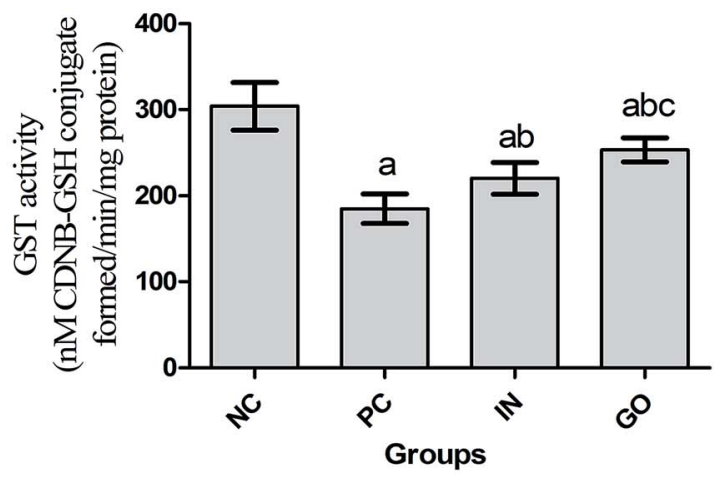

B
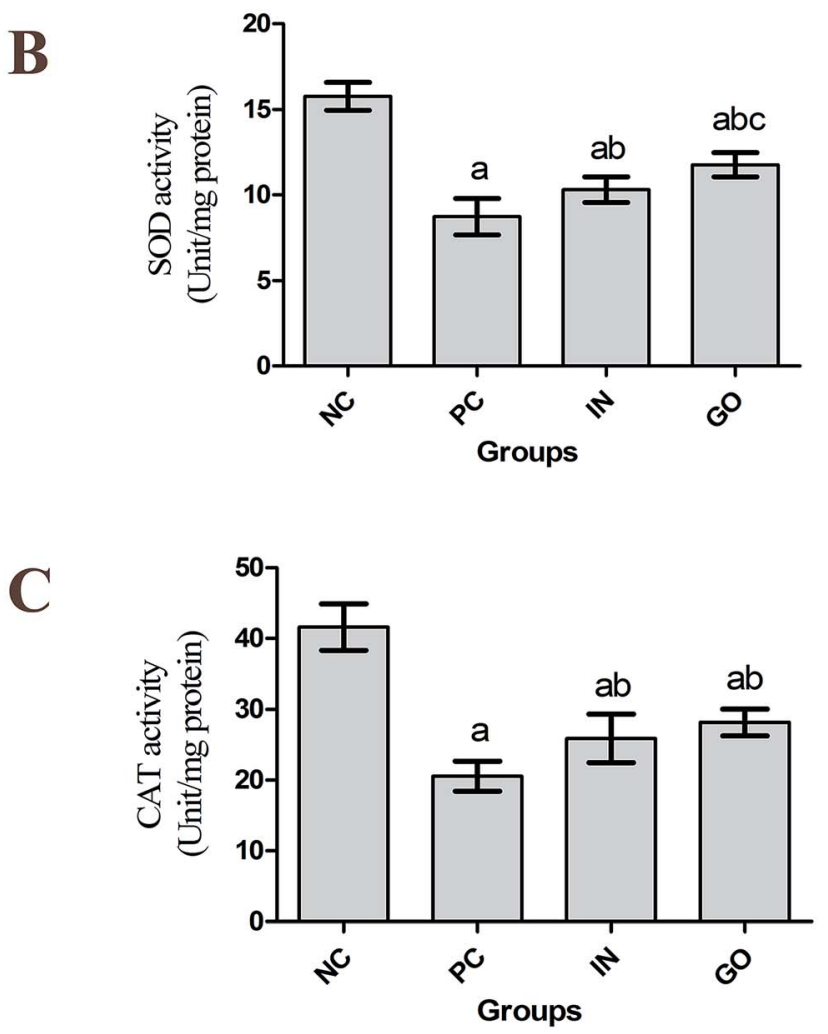

Fig. 7 Effect of GO with respect to IN (a standard prebiotic) on oxidant and anti-oxidant status in experimental colon carcinogenesis. (a) GST activity, (b) SOD activity and (c) CAT activity values are expressed as mean \pm SD $(n=6)$. (a) Significantly $(p<0.05)$ different to that of NC, (b) significantly $(p<0.05)$ different to that of PC and (c) significantly $(p<$ $0.05)$ different to that of $I N$.

group supplemented with IN. A more pronounced effect was found when GO is supplemented in the diet of the respective test group thus we observed $27.01 \%$ more GST activity when compared with the DMH alone group, i.e. PC. Induction of GST levels is a key mechanism of BA in CRC management as it enhances GST expression which in turn reduces oxidative stress caused by various genotoxic agents. ${ }^{\mathbf{6 1}}$ Detoxification of xenobiotics is the main strategy adapted by biological systems for cancer prevention and colonic GST plays a major part in residual detoxification. Our results are in agreement with similar studies that a dietary bioactive compound like GO 
contributes towards the cellular defensive mechanism by enhancing antioxidative potential. ${ }^{83}$

\subsection{Estimation of the SOD levels in the colonocytes}

SOD members ( $\mathrm{Mn}, \mathrm{Cu}$ and $\mathrm{Zn}$ SOD) catalyze dismutation of superoxide to $\mathrm{O}_{2}$ and hydrogen peroxide to water. ${ }^{84}$ Our results indicated that the activities of SOD were significantly $(p<0.05)$ lower by $44.8 \%$ in colonic tissues of PC compared to NC. The changes in SOD levels are detailed in Fig. 7(B). From Fig. 7(B) we can observe an elevated antioxidant activity of $15.3 \%$ in IN with respect to the $\mathrm{DMH}$ alone treated group (PC). The activity of SOD further got better in GO which is $25.85 \%$ and $12.41 \%$ more than PC and IN, respectively. The observed protection conferred by GO against DMH-induced CRC is mainly due to its fermentation product. BA and PA decrease $\mathrm{H}_{2} \mathrm{O}_{2}$ levels and increase SOD activity in colonocytes nullifying the effect of ROS and LPO, reducing the activity of procarcinogenic enzymes and number of preneoplastic lesions. SOD acting with other antioxidants is also responsible for reduced colonic damage by reducing tumor burden and multiplicity. ${ }^{84}$

\subsection{Estimation of the CAT levels in the colonocytes}

CAT stands in the forefront of defense against oxidative stress and maintains the balance between production and removal of ROS within cells. ${ }^{85}$ Fig. 7(C) shows the effect of DMH on the levels of CAT in colon tissues and respective changes monitored upon incorporation of IN and GO along with DMH. The CAT activity was quite a bit higher in the NC i.e. normal group than in all other test groups. A 50.54\% fall in this activity was observed in the DMH alone group or PC but upon incorporation of prebiotics in the diet a significant $(p<0.05)$ increase in activity by $20.60 \%$ and $26.97 \%$ was seen for IN and GO, respectively, compared to the positive control. The results from this study show that treatment with GO almost reversed all DMH-induced oxidative stress. We propose that GO supplementation increases CAT levels in colonocytes and helps maintain oxidant/antioxidant balance. This increase in antioxidant levels also played a positive role in the reduction of CRC development and this fact is also supported by the SEM and histological findings in the study.

\section{Conclusions}

In summary, this study deals with inclusion of GO in the diet and its related therapeutic properties i.e. anticancer and antioxidant. The observed results show that GO is a potential prebiotic and selectively stimulates growth and colonization of Lactobacillus sp. and Bifidobacterium sp. over others. Moreover, SCFAs released upon fermentation of GO act synergistically with probiotic bacteria reducing the action of pro-carcinogens, slowing tumor formation and progression in the colon. Synbiotic actions also scavenge free radicals produced by dietary xenobiotics and maintain homeostasis by activating various enzymatic and non-enzymatic antioxidants. Thus, GO dilutes the overall oxidative stress and helps in CRC management.

\section{Conflict of interest}

There is no conflict of interest among any of the authors.

\section{Abbreviations}

$\begin{array}{ll}\text { CDNB } & \text { 1-Chloro-2,4-dinitrobenzene } \\ \text { DMH } & \text { 1,2-Dimethyl hydrazine } \\ \text { DCF } & 2^{\prime}, 7^{\prime} \text {-Dichlorofluorescein } \\ \text { DCFH-DA } & 2^{\prime}, 7^{\prime} \text {-Dichlorofluorescin diacetate } \\ \text { DTNB } & 5,5 \text {-Dithio-bis-(2-nitrobenzoic acid) } \\ \text { AA } & \text { Acetic acid } \\ \text { BA } & \text { Butyric acid } \\ \text { CAT } & \text { Catalase } \\ \text { CRC } & \text { Colorectal cancer } \\ \text { GO } & \text { Gum odina } \\ \text { GSH } & \text { Glutathione } \\ \text { GST } & \text { Glutathione- } S \text {-transferase } \\ \text { IN } & \text { Inulin } \\ \text { LA } & \text { Lactic acid; } \\ \text { LPO } & \text { Lipid peroxidation; } \\ \text { NC } & \text { Negative control } \\ \text { PBS } & \text { Phosphate buffered saline } \\ \text { PC } & \text { Positive control } \\ \text { PA } & \text { Propionic acid } \\ \text { ROS } & \text { Reactive oxygen species } \\ \text { SCFA } & \text { Short chain fatty acids } \\ \text { SOD } & \text { Superoxide dismutase } \\ \text { TBARS } & \text { Thiobarbituric acid reactive substances } \\ & \end{array}$

\section{Acknowledgements}

The authors are grateful to the Department of Science and Technology, Ref no. IF120556, Government of India for providing financial support and also thankful to University Potential for Excellence, Phase - II, University Grant Commission, Government of India for providing instrumental support.

\section{References}

1 D. Mitra, A. K. Jena, A. De, M. Das, B. Das and A. Samanta, Food Funct., 2016, 7, 3064-3072.

2 C. V. Cervantes-Martínez, L. Medina-Torres, R. F. GonzálezLaredo, F. Calderas, G. Sánchez-Olivares, E. E. HerreraValencia, J. A. Gallegos Infante, N. E. Rocha-Guzman and J. Rodríguez-Ramírez, LWT-Food Sci. Technol., 2014, 55, 426-435.

3 A. K. Samanta, N. Jayapal, C. Jayaram, S. Roy, A. P. Kolte, S. Senani and M. Sridhar, Bioact. Carbohydr. Diet. Fibre, 2015, 5, 62-71.

4 G. R. Gibson, K. P. Scott, R. A. Rastall, K. M. Tuohy, A. Hotchkiss, A. Dubert-Ferrandon, M. Gareau, E. F. Murphy, D. Saulnier, G. Loh, S. Macfarlane, N. Delzenne, Y. Ringel, G. Kozianowski, R. Dickmann, I. Lenoir-Wijnkook, C. Walker and R. Buddington, Food Sci. Tech. Bull. Funct. Foods, 2010, 7, 1-19. 
5 R. P. De Souza Oliveira, P. Perego, M. N. De Oliveira and A. Converti, LWT-Food Sci. Technol., 2011, 44, 520-523.

6 G. R. Gibson and M. B. Roberfroid, J. Nutr., 1995, 125, 14011412.

7 G. T. Choque Delgado, W. M. D. S. C. Tamashiro, M. R. M. Junior, Y. M. F. Moreno and G. M. Pastore, Food Res. Int., 2011, 44, 3167-3173.

8 S. K. Singdevsachan, P. Auroshree, J. Mishra, B. Baliyarsingh, K. Tayung and H. Thatoi, Bioact. Carbohydr. Diet. Fibre, 2016, 7, 1-14.

9 B. Gullón, P. Gullón, F. Tavaria, J. L. Alonso and M. Pintado, Food Funct., 2015, 6, 525-531.

10 E. N. Fissore, C. S. Domingo, L. N. Gerschenson and L. Giannuzzi, Food Funct., 2015, 6, 1667-1674.

11 Z. Liu, X. Lin, G. Huang, W. Zhang, P. Rao and L. Ni, Anaerobe, 2014, 26, 1-6.

12 S. He, X. Wang, Y. Zhang, J. Wang, H. Sun, J. Wang, X. Cao and Y. Ye, Carbohydr. Polym., 2016, 151, 295-304.

13 S. M. Sanches Lopes, M. G. Francisco, B. Higashi, R. T. Ribeiro de Almeida, G. Krausová, E. J. Pilau, J. E. Goncalves, R. A. C. Goncalves and A. J. B. de Oliveira, Carbohydr. Polym., 2016, 152, 718-725.

14 X. Wang and G. R. Gibson, J. Appl. Bacteriol., 1993, 75, 313380.

15 N. Salazar, P. Ruas-Madiedo, S. Kolida, M. Collins, R. Rastall, G. Gibson and C. G. de los Reyes-Gavilán, Int. J. Food Microbiol., 2009, 135, 260-267.

16 N. M. Delzenne and N. Kok, J. Nutr. Sci. Vitaminol., 2001, 73, 456-458.

17 L. Lichtenstein, I. Avni-Biron and O. Ben-Bassat, Best Pract. Res., Clin. Gastroenterol., 2016, 30, 73-80.

18 M. DeBarros and S. R. Steele, J. Cancer, 2013, 4, 270-280.

19 D. Commane, R. Hughes, C. Shortt and I. Rowland, Mutat. Res., 2005, 591, 276-289.

20 P. Ambalam, M. Raman, R. K. Purama and M. Doble, Best Pract. Res., Clin. Gastroenterol., 2016, 30, 119-131.

21 G. Cuevas-Ramos, C. R. Petit, I. Marcq, M. Boury, E. Oswald and J. P. Nougayrede, Proc. Natl. Acad. Sci. U. S. A., 2010, 107, 11537-11542.

22 K. Mima, Y. Sukawa, R. Nishihara, Z. R. Qian, M. Yamauchi and K. Inamura, JAMA Oncology, 2015, 1, 653-661.

23 M. R. Rubinstein, X. Wang, W. Liu, Y. Hao, G. Cai and Y. W. Han, Cell Host Microbe, 2013, 14, 195-206.

24 C. K. Hsu, J. W. Liao, Y. C. Chung, C. P. Hsieh and Y. C. Chan, J. Nutr., 2004, 134, 1523-1528.

25 M. Mendis and S. Simsek, Food Hydrocolloids, 2014, 42, 239243.

26 M. Bauer-Marinovic, S. Florian, K. Müller-Schmehl, H. Glatt and G. Jacobasch, Carcinogenesis, 2006, 27, 1849-1859.

27 E. Hijova, V. Szabadosova, L. Strojny and A. Bomba, Bratisl. Lek. Listy, 2014, 115, 76-79.

28 B. Lin, J. Gong, Q. Wang, S. Cui and H. Yu, Food Hydrocolloids, 2011, 25, 180-188.

29 M. Thangaraju, K. N. Carswell, P. D. Prasad and V. Ganapathy, Biochem. J., 2009, 417, 379-389.

30 B. Mukherjee, A. Samanta and S. C. Dinda, Trends Appl. Sci. Res., 2006, 1, 309-316.
31 A. Samanta, D. Ojha and B. Mukherjee, Nat. Sci., 2010, 2, 494-505.

32 S. C. Dinda, B. Mukherjee and A. Samanta, Orient. Pharm. Exp. Med., 2011, 11, 131-136.

33 P. S. Roy, A. Samanta, M. Mukherjee, B. Roy and A. Mukherjee, Ind. Eng. Chem. Res., 2013, 52, 15728-15745.

34 A. K. Bhattacharyya and C. V. N. Rao, Can. J. Chem., 1964, 42, 107-112.

35 A. K. Bhattacharyya and A. K. Mukherjee, Bull. Chem. Soc. Jpn., 1964, 37, 1425-1429.

36 K. K. Nair, S. Kharb and D. K. Thompkinson, Food Rev. Int., 2010, 26, 189-203.

37 V. R. Sinha, A. A. Al-Azaki and R. V. Kumar, Carbohydr. Polym., 2011, 83, 1492-1498.

38 T. V. Wiele, P. V. Abbeele, W. Ossieur, S. Possemiers and M. Marzorati, Laboratory Microbial Ecology and Technology, Prodigest, Gent, 2015.

39 T. van de Wiele, N. Boon, S. Possemiers, H. Jacobs and W. Verstraete, J. Appl. Microbiol., 2007, 102, 452-460.

40 R. Satish Kumar, P. Kanmani, N. Yuvaraj, K. A. Paari, V. Pattukumar, C. Thirunavukkarasu and V. Arul, Appl. Biochem. Biotechnol., 2012, 166, 620-631.

41 A. Verma and G. Shukla, J. Funct. Foods, 2013, 5, 991-996.

42 C. Colussi, S. Fiumicino, A. Giuliani, S. Rosini, P. Musiani, C. Macri, C. S. Potten, M. Crescenzi and M. Bignami, J. Natl. Cancer Inst., 2001, 93, 1534-1540.

43 A. Basu, A. Bhattacharjee, S. Hajra, A. Samanta and S. Bhattacharya, Redox Rep., 2016, DOI: 10.1080/ 13510002.2016.1260192.

44 J. E. Paulsen, E. Namork and J. Alexander, Anticancer Res., 2005, 25, 3883-3888.

45 N. P. Singh, M. T. McCoy, R. R. Tice and E. L. Schneider, Exp. Cell Res., 1988, 175, 184-191.

46 J. P. Robinson, Curr Protoc Cytom, Wiley, 2001, Oxidative metabolism, 2, 9.7, 9.7.1-9.7.14.

47 H. Ohkawa, N. Ohishi and K. Yagi, Annal. Biochem., 1979, 95, 351-358.

48 J. Sedlack and R. N. Lindsay, Annal. Biochem., 1968, 25, 192205.

49 W. H. Habig, M. J. Pabst and W. B. Jacoby, J. Biol. Chem., 1974, 249, 7130-7139.

50 S. Marklund and G. Marklund, Eur. J. Biochem., 1974, 47, 469-474.

$51 \mathrm{H}$. Luck, A spectrophotometric method for estimation of catalase, Methods of enzymatic analysis, ed. HV Bergmeyer, Academy Press, New York, 1963, pp. 886-888.

52 J. Fernandez, S. Redondo-Blanco, I. Gutierrez-del-Rio, E. M. Miguelez, C. J. Villar and F. Lombo, J. Funct. Foods, 2016, 25, 511-522.

53 D. Bosscher, A. Breynaert, L. Pieters and N. Hermans, J. Physiol. Pharmacol., 2009, 60, 5-11.

54 S. Sivaprakasam, P. D. Prasad and N. Singh, Pharmacol. Ther., 2016, 164, 144-151.

55 B. G. Heerdt, M. A. Houston and L. H. Augenlicht, Cell Growth Differ., 1997, 8, 523-532.

56 T. R. Qamar, F. Syed, M. Nasir, H. Rehman, M. N. Zahid, R. H. Liu and S. Iqbal, Nutrients, 2016, 8, 465. 
57 O. Hernandez-Hernandez, M. L. Sanz, S. Kolida, R. A. Rastall and F. J. Moreno, J. Agric. Food Chem., 2011, 59, 1194911955.

58 K. Pokusaeva, G. F. Fitzgerald and D. van Sinderen, Genes Nutr., 2011, 6, 285-306.

59 E. Klewicka, Z. Zdunczyk and J. Juskiewicz, Eur. Food Res. Technol., 2009, 229, 153-157.

60 A. K. Samanta, A. P. Kolte, M. Chandrasekhariah, A. Thulasi, K. T. Sampath and C. S. Prasad, Indian Dairyman, 2007, 59, 58-61.

61 E. S. L. Chong, World J. Microbiol. Biotechnol., 2014, 30, 351374.

62 S. Tavolaria, A. Munarinia, G. Storcia, S. Lauferc, P. Chiecoa and T. Guarnieria, Cancer Lett., 2012, 321(2), 187-194.

63 R. Satish Kumar, P. Kanmani, N. Yuvaraj, K. A. Paari, V. Pattukumar, C. Thirunavukkarasu and V. Arul, Appl. Biochem. Biotechnol., 2012, 166, 620-631.

64 P. L. Sequetto, T. T. Oliveira, I. R. Maldonado, L. E. F. Augusto, V. J. Mello, V. R. Pizziolo, M. R. Almeida, M. E. Silva and R. D. Novaes, Food Chem. Toxicol., 2014, 7(64), 200-209.

65 J. Rafter, M. Bennett, G. Caderni, Y. Clune, R. Hughes, P. C. Karlsson, A. Klinder, M. O'Riordan, G. C. O'Sullivan, B. Pool-Zobel, G. Rechkemmer, M. Roller, I. Rowland, M. Salvadori, H. Thijs, J. Van Loo, B. Watzl and J. K. Collins, Am. J. Clin. Nutr., 2007, 85, 488-496.

66 W. R. Bruce and D. E. Corpet, Eur. J. Cancer Prev., 1996, 5, 4147.

67 V. D. Chadha and D. K. Dhawan, Oncol. Res., 2009, 18, 17-23. 68 S. Patel and A. Goyal, 3 Biotech, 2012, 2, 115-125.

69 R. K. L. Leu, Y. Hu, I. L. Brown, R. J. Woodman and G. P. Young, Carcinogenesis, 2010, 31, 246-251.
70 J. Zhang, G. Wu, R. S. Chapkin and J. R. Lupton, J. Nutr., 1998, 128, 1262-1269.

71 M. Raman, P. Ambalam, K. K. Kondepudi, S. Pithva, C. Kothari, A. T. Patel, R. K. Purama, J. M. Dave and B. R. M. Vyas, Gut Microbes, 2013, 4, 181-192.

72 D. L. Oberreuther-Moschner, G. Jahreis, G. Rechkemmer and B. L. Pool-Zobel, Br. J. Nutr., 2004, 91, 925-932.

73 S. B. Nimse and D. Pal, RSC Adv., 2015, 5, 27986-28006.

74 B. Badhani, N. Sharma and R. Kakkar, RSC Adv., 2015, 5, 27540-27557.

75 R. G. Allen and M. Tresini, Free Radical Biol. Med., 2000, 28, 463-499.

76 S. Yano and D. F. Tierney, Biochem. Biophys. Res. Commun., 1989, 164, 1143-1148.

77 C. Siquet, F. Paiva-Martins, J. L. F. C. Lima, S. Reis and F. Borges, Free Radical Res., 2006, 40, 433-442.

78 Y. Zhang, S. Y. Chen, T. Hsu and R. M. Santella, Carcinogenesis, 2002, 23, 207-211.

79 M. Y. Lin and F. J. Chang, Dig. Dis. Sci., 2000, 45, 1617-1622.

80 H. Langemann, J. Torhorst, A. Kabiersch, W. Krenger and C. G. Honegger, Int. J. Cancer, 1989, 43, 1169-1173.

81 V. Manju, V. Balasubramaniyan and N. Nalini, Cell. Mol. Biol. Lett., 2005, 10, 535-551.

82 L. T. Laughlin, B. A. Bernat and R. N. Armstrong, Chem.-Biol. Interact., 1998, 111, 41-50.

83 J. Sauer, K. K. Richter and B. L. Pool-Zobel, Br. J. Nutr., 2007, 97, 928-937.

84 R. C. G. Martin, Y. Li, Q. Liu, D. F. Barker, M. A. Doll and D. W. Hein, Cancer Invest., 2010, 28, 813-819.

85 G. D. Mao, P. D. Thomas, G. D. Lopaschuk and M. J. Poznansky, J. Biol. Chem., 1993, 268, 416-420. 